\title{
Reliability and Factor Analyses of a Teacher Efficacy Scale for Nigerian Secondary School Teachers
}

Bamidele Abiodun Faleye

Department of Educational Foundations and Counselling, Ile-Ife

Nigeria

bamidelefaleye@yahoo.com

Postal Address: Department of Educational Foundations and Counselling, Faculty of Education. Obafemi Awolowo University. Ile-Ife. Nigeria.

(C) Education \& Psychology I+D+i and Editorial EOS (Spain) 


\begin{abstract}
Introduction. The suitability of 52 items for measuring Teacher Efficacy was investigated with the aim of developing and validating a Teacher Efficacy Scale (TES) for Nigerian secondary school teachers.
\end{abstract}

Method. The TES was administered on 2400 teachers (mean age $=36.75$ years). Data were subjected to factor and reliability analyses.

Results. Twenty-eight items were dropped, resulting in the retention of 24 items on the final version. The instrument had a Cronbach's Alpha and Split-half reliability coefficients of 0.88 and 0.90 respectively. Exploratory Factor Analysis revealed that the items on the final version of TES loaded on two factors, which accounted for $46.40 \%$ of the total scale variance. They are 'efficacy to influence students' learning' (Cronbach's Alpha $=0.86$ ), and 'efficacy to enlist parental support in students' learning' (Cronbach's Alpha $=0.72$ ).

Conclusion. It was concluded that the 24-item TES in its present form was capable of effectively measuring TE among secondary school teachers.

Keywords: Efficacy, Teacher Efficacy Scale, Scale Development, Reliability, Factor Analysis

Received: 18/05/07 Initial Acceptance: 01/09/07 Definitive Acceptance: 16/09/08 


\section{Resumen}

Introducción. Se investigó la adecuación de 52 ítems para la medición de la eficacia docente, con el fin de elaborar y validar una Escala de Eficacia Docente (EED) para los profesores de Educación Secundaria de Nigeria.

Método. La EED se administró a 2.400 profesores (edad media $=36,75$ años). Se sometieron los datos a análisis de factores y de fiabilidad.

Resultados. Se eliminaron veintiocho ítems, quedando la versión final en 24 ítems. En cuanto a la fiabilidad del instrumento, las coeficientes Alfa de Cronbach y por dos mitades fueron 0,88 y 0,90 respectivamente. Un análisis factorial exploratorio descubrió que los ítems de la versión final de la EED dan mayor peso a dos factores, explicando así $46,40 \%$ del total de la varianza de la escala. Los dos factores son 'la eficacia a la hora de influir en el aprendizaje de los alumnos' (Alfa de Cronbach =0,86), y 'la eficacia a la hora de conseguir el apoyo de los padres en la aprendizaje de los alumnos' (Alfa de Cronbach $=0,72$ ).

Conclusión. Se concluyó que la EED con sus 24 ítems en su forma actual es capaz de medir eficazmente la ED de los profesores de Educación Secundaria.

Palabras clave: Eficacia, Escala de Eficacia Docente, Elaboración de Escalas, Fiabilidad, Análsis Factorial

Recibido: 09/01/07 Aceptación Provisional: 05/18/07 Aceptación Definitiva: 09/16/08 


\section{Introduction}

Teacher Efficacy (TE) has been defined as teachers' belief or conviction that they can influence how well students learn, even those who may be difficult and unmotivated (Guskey \& Passaro, 1994). In the same vein, it has also been defined as a judgment of teachers' capabilities to bring about desired outcomes of students' engagement and learning (Tschannen-Moran \& Woolfolk-Hoy, 2001). This concept has been linked to a number of factors such as teacher's behaviour and attitude; teacher's organisational skills and enthusiasm for teaching (Allinder, 1994; Hall, Burley, Villeme \& Brockmeier, 1992). Thus, the concept of TE has been found to be an important construct in education (TschannenMoran and Woolfolk-Hoy, 2001). The development of instrument (such as Teacher Efficacy Scale - TES) for the measurement of the construct has generated heated debate among researchers especially in the United States of America (USA). While some TE research were based on the tradition of the Social Learning theory propounded by Rotters (1966), some others were based on the conceptual strand of Social Cognitive theory postulated by Bandura (1977). The belief of the social learning theorists is that the control of reinforcement of teachers' actions lies either within them or in the environment. Those who belief that they can teach very difficult or unmotivated students have a belief that the "...reinforcement of teaching activities lies within the teachers' control or is internal" (Tschannen-Moran \& Woolfolk-Hoy, 2001). On the other hand, those who belief that the environment overwhelmingly influence the reinforcement of their teaching actions demonstrate a belief that reinforcement of their teaching is beyond their control (i.e. external to them).

Social cognitive psychology researchers are of the view that self-efficacy beliefs influence performance. Individuals have been found to develop certain beliefs about how they can cope with certain tasks in specific situations (Magogwe, 2006). According to Bandura's (1986) social cognitive theory, the manner in which individuals judge their capability to perform certain tasks, or their self-efficacy beliefs, foretell their potential to accomplish such tasks. Thus, diverse forms of TE scales based on different methodologies, samples and techniques have been developed based on the theories of Rotter (1966) and Bandura (1986). 
From 1976, when researchers from Rand Corporation pioneered research activities on the development of instrument for the measurement of Teacher Efficacy (TE) to the most recent times, there have been series of reports of measurement defects by researchers across cultures and national boundaries (Brouwers, 2003; Campbell, 1996; Tschannen-Moran \& Woolfolk-Hoy, 2001). For example, the outcomes of factor analysis (whether Confirmatory Factor Analysis [CFA] or Exploratory Factor Analysis [EFA]) of TE scales have yielded different results even where similar instruments were used in data collection (Coladarci \& Fink, 1995). It can be inferred from these differences in results that TE may be contextspecific as thought by Pajares (1996). The context-specificity of TE is dependent to a large extent on the situation of the mind of the respondents (i.e. teachers) and the condition under which they work. This perhaps could be the reason why Bandura (1997) proposed that a TE belief arises from the interplay of three factors. Bandura referred to this interplay as 'triadic reciprocal causation'. The three factors in the interplay are environment, behaviour and personal factors.

Evidence from literature revealed that the various versions of TE scales were developed mainly in the United States of America. In Nigeria, no serious attention has been given to the development of measuring instrument for capturing an elusive construct as TE (Tschannen-Moran \& Woolfolk-Hoy, 2001). One thing to note is that the environment in America under which a typical American schoolteacher works is quite different from that in Nigeria. It is also a matter of common knowledge that the societal value and orientation in America are different from those in Nigeria. The process of teacher preparation in Nigeria is also different from that of the United States of America (Okebukola, 2002). What teachers in America will regard as serious constraints to achieving students' learning may not necessarily be seen as such by teachers in Nigeria. Therefore, there is the need to develop an instrument in Nigeria to measure the TE of teachers in the country.

The interest in this study was aroused by many factors. There is the need for having a TE scale that will be relevant to Nigeria's environmental realities and based on Nigerian teachers' and personality factors (Achimugu, 2001). A second reason is that a definitive, empirically derived factor structure of TES has not been agreed upon. Variations exist in the factor structure of exploratory as well as confirmatory factor analyses of Teacher Efficacy Scale (TES) across researchers (Browers, 2003; Campbell, 1996 and Tschannen-Moran \& Woolfolk-Hoy, 2001) and also, to provide easy accessibility of the scale to researchers and/or 
authors based in institutions not connected to the world-wide-web (www). Other factors are variations in levels of development (whether economic, social or technological) in the countries of North America (where the development of the scale has been given serious attention) and in Nigeria; and the recommendations by many authors such as TschannenMoran, Woolfolk-Hoy \& Hoy (1998), Henson (2001), Tschannen-Moran \& Woolfolk-Hoy, 2001 and Brouwers (2003) that TE scales be developed or adapted and validated for different cultures and national boundaries.

Suffice it to state that the recommendations of these authors may have been premised on the proposition that respondents to items validated in a setting are likely to respond differently to similar items in another setting. Since the process of teacher preparation, the conditions under which the teacher works and the orientation of the learners the teacher deals with in Nigeria are different from those present in America, there was a need to develop an instrument in Nigeria to measure the TE of secondary school teachers.

The specific objective which this study intended to achieve was to:

(a) develop a TE scale for Nigerian secondary school teachers;

(b) determine the reliability of the TE scale.

(c) estimate the factorial validity of the scale.

In the pursuant of these objectives, the following research questions were investigated:

(a) What items would be adjudged to measure TE?

(b) What is the internal consistency reliability of the scale?

(c) What is the Factorial Validity of the TES?

\section{Method}

\section{Sample}

The population for this study consisted of all the in-service secondary school teachers in Nigeria. Due to restrictions imposed by factors of time, expense and accessibility, 2400 subjects were drawn from six states out of the population identified. Multi-stage sampling technique was used in selecting the teachers included in the study. The secondary school teachers were selected using the six geo-political zones in Nigeria as the first stratum. From each of the zones, one state was selected using simple random technique. From each of the 
selected states, purposive method was employed to select a total of 400 teachers totaling 2400 across the country. The teachers were selected from 2 federal government-owned, 12 state government-owned and 6 privately-owned secondary schools. In all, 12 federal governmentowned secondary schools; 76 state government-owned secondary schools and 36 privatelyowned secondary schools were selected. Twenty teachers were selected from each of the twenty schools selected in each state amounting to 400 teachers for each state and 2,400 for the six states. A total of 2400 (consisting of 1400 male and 1000 female) secondary school teachers were included in the study. Their average age was 36.75 years. Only 2071 (consisting of 1327 males and 744 females) returned the instrument administered on them. Thus, the return rate was $86.29 \%$.

\section{Instrument}

The instrument used for the study was a 52-item scale called Teacher Efficacy Scale (TES) (See Appendix 5). It was developed through the adaptation of the items on the Bandura's (1990) Teacher Self-Efficacy Scale (TSS). The items on Bandura's (1990) scale turned from question to statements, and additional items were generated by the researcher. The items relate to the areas of teachers' activities such as the efficacy to bring about students' learning, efficacy to instill discipline in students, efficacy to enlist parental involvement in school and learning activities, efficacy to receive the cooperation of other teachers in the school, testing efficacy, efficacy to reach the poor learners in the classroom and efficacy to enlist the participation and support of neighbourhood universities and colleges in the activities of the school. All the items centered on the two dimensions of self-efficacy and outcome expectation of teachers for each of their activities (Bandura, 1977).

The response format for the scale was the Likert (1932) type with five options of SA = Strongly Agree, $\mathrm{A}=$ Agree, $\mathrm{U}=$ Undecided, $\mathrm{D}=$ Disagree, $\mathrm{SA}=$ Strongly Disagree.

A pilot study was conducted to test the reliability of the initial items on the TES. Prior to the time it was taken to the field; the TES was subjected to expert judgment of five experts. Two of these experts were from Psychology while the remaining three were Measurement experts. They appraised the items on the basis of ambiguity, relevance and sentence structure. In the process, twelve items were dropped and 52 retained. The administration of the draft 
scale on 100 secondary school teachers yielded a mean efficacy value of 3.53 , with minimum and maximum scores of 1.94 and 4.51 respectively, and a variance of 0.54 .

The sub-scale factors were arrived at after a careful study of the various dimensions of teacher efficacy as evidenced in the works of researchers on the construct. For example, Tschannen-Moran; Woolfolk-Hoy and Hoy (1998) conducted a comprehensive review of literature on teacher efficacy. They concluded that teacher efficacy had six aspects of students' learning, discipline, parental involvement, testing, reaching the poor in the class and overcoming work challenges. The items measuring each of the sub-scales are as listed in front of each factor as contained in Table 1.

Table 1. TES Sub-Scale Factors and their Items

\begin{tabular}{lll}
\hline Factors & \multicolumn{1}{c}{ Sub-scale } & \multicolumn{1}{c}{ Items } \\
\hline 1 & Student Learning & $2,3,4,5,7,8,9,10,12,13,14,16,19,32$ and 46 \\
2 & Discipline & $11,15,20,21,22,23,36,42,43,44$, and 48 \\
3 & Parental Involvement & $6,18,24,25,26,27,28,29,30$ and 31 \\
4 & Testing & $17,33,38,39,40$ and 41 \\
5 & Reaching the Poor in the Class & $1,34,35$ and 47 \\
6 & Overcoming Work Challenges & $37,45,49,50,51$ and 52 \\
\hline
\end{tabular}

Cronbach's Alpha reliability test was conducted on each of the sub-scale. The result obtained showed that the Alpha coefficients for: Students' Learning was 0.68; Discipline was 0.64; Parental Involvement was 0.63; Testing was 0.65; Reaching the Poor in the Class was 0.60 and Overcoming Work Challenges was 0.59. Reliability test was also conducted on the whole data collected for pilot testing. The reliability tests conducted on the data included Cronbach's Alpha (Cronbach, 1951), Spearman Brown Split-half test and thirdly, Guttman split- half coefficient. The coefficients obtained were $0.63,0.67$ and 0.66 respectively. These were considered satisfactory.

The study employed the use of reliability analyses in determining the retention or rejection (and removal) of items on the scale. Two features of each of the items were examined before taking item retention decision on each of the item. The first is the use of "Corrected Item-total Statistics" (CIS) as well as "Cronbach's Alpha if Item Deleted" (CAID). These two are obtainable using the reliability analysis tool on the Statistical Package for Social Sciences (SPSS). 
The item retention decisions were taken using a combination of the two statistics mentioned in the preceding paragraph. Any item having CIS of less than 0.34 was removed from the scale. Such items would show a higher CAID than what obtained for most other items on the scale. The implication of this was that when such items were deleted, the Alpha coefficient of the scale increased.

\section{Procedure}

Data were collected by the researcher and field assistants who traveled to each of the selected schools. The assistance of the school management was sought in obtaining the cooperation of teachers to respond to the TES items. The supervision of the actual administration and collection of the TES was administered with the assistance of one of the teachers in each school. Thus, the exercise lasted for two weeks. A total of 2400 instruments were administered on the selected sample. Out of these, only 2071 were returned. Thus, a return rate of $86.29 \%$ was achieved. This percentage represents those who return the TES given to them for completion during data collection.

Data was analysed using Exploratory Factor Analysis (EFA) and reliability analyses techniques. The factor structure of the TES was investigated by subjecting the initial scale to EFA. Specifically, EFA was conducted on the responses in order to identify the factors on which the items on the scale loaded. Cronbach's coefficient Alpha was employed for taking decisions on item retention.

Cronbach's coefficient alpha, Spearman Brown's and Guttman's Split-half coefficients were used to determine the reliability of the scale. Inter-item correlation was carried out using the SPSS to determine the level of relatedness of the items to each of the factors that emerged from the EFA. Finally, inter-school comparison of responses was carried out to investigate the influence of school ownership structure, gender and length of teaching experience on TE. One-way Analysis of variance was employed to investigate the influence of school ownership structure and teaching experience while t-test was employed to investigate the influence of gender.

\section{Results}


Research Question 1: What items would be adjudged to measure TE?

The 52-items contained on the TES which was administered on the selected secondary school teachers is as shown in Appendix 1.

There was the need to examine the statistics for each of the items in order to take appropriate decision on items retention/deletion. Table 2 shows the mean and standard deviation for each of the 52 items on the TES.

Table 2. Item Mean and Standard Deviation for the 52-Item Version of TES

\begin{tabular}{lll}
\hline Item No. & Mean & S. D. \\
& & \\
\hline 1 & 4.3103 & .84908 \\
2 & 4.0714 & 1.02532 \\
3 & 3.6627 & 1.27094 \\
4 & 4.3992 & 4.3992 \\
5 & 3.5762 & 1.42364 \\
6 & 3.9794 & 1.01829 \\
7 & 4.3897 & 4.3992 \\
8 & 3.9722 & .97630 \\
9 & 2.7929 & 1.29241 \\
10 & 4.1619 & .99521 \\
11 & 4.2635 & .88609 \\
12 & 3.5722 & .98456 \\
13 & 4.3357 & .85343 \\
14 & 4.1833 & .99428 \\
15 & 3.7881 & 1.13589 \\
16 & 3.6032 & 1.11655 \\
17 & 3.9357 & .96227 \\
18 & 3.6008 & 1.14971 \\
19 & 3.7929 & 1.15548 \\
20 & 4.2294 & .86532 \\
21 & 4.3175 & .87186 \\
22 & 4.3111 & .91151 \\
23 & 3.0127 & 1.37138 \\
24 & 3.9365 & 1.11774 \\
25 & 4.4135 & .91305 \\
26 & 3.3421 & 1.16254 \\
27 & 3.3421 & 1.32597 \\
28 & 3.6984 & 1.04292 \\
29 & 3.5405 & 1.05486 \\
30 & 3.5325 & 1.08629 \\
31 & 3.4984 & 1.12697 \\
32 & 4.1000 & .91645 \\
33 & 4.1611 & .91645 \\
34 & 4.2190 & .94130 \\
35 & 4.4429 & .83931 \\
36 & 3.5048 & 1.30100 \\
37 & 4.1095 & .88894 \\
38 & 4.0508 & .92565 \\
39 & 4.2137 & 1.15242 \\
40 & 4.1278 & .88336 \\
41 & 2.9278 & 1.31842 \\
42 & 2.6992 & 1.40548 \\
43 & 2.6698 & 1.50842 \\
44 & 2.6516 & 1.61802 \\
45 & 2.8127 & 1.30430 \\
46 & 2.8786 & 1.25039 \\
47 & 2.8183 & 1.21983 \\
48 & 2.3690 & 1.32592 \\
49 & 2.4437 & 1.41112 \\
50 & 2.7127 & 1.46551 \\
51 & 2.6603 & \\
52 & 2.5349 & \\
& & \\
& & \\
& &
\end{tabular}


The item with the highest mean is item 35 (mean=4.44) and the same item has the lowest standard deviation (0.84). Item 48 has the lowest mean (2.37) while item 44 has the highest standard deviation (1.62). It means responses differed mostly on item 44. Some agreed strongly with it while others disagreed on the same item.

The taking of decision on the removal of weak items from the 52-item TES was taken through the use of an approach. The approach used isthat taken from 'Corrected Item-Total Correlation' which indicates the new coefficient of 'Cronbach's Alpha after a weak item had been removed from the scale. The set of items having low 'Corrected Item-Total Correlation' (of less than 0.2) are those that will increase the Alpha coefficient of the scale when they are deleted. Table 3 shows the Item-Total Statistics needed for taking decisions on items that were to be deleted.

Table 3. Item-Total Statistics for 52-Item versiono f TES

\begin{tabular}{|c|c|c|c|c|c|}
\hline Item No. & $\begin{array}{l}\text { Scale Mean } \\
\text { If Item Deleted }\end{array}$ & $\begin{array}{l}\text { Scale Variance } \\
\text { If Item Deleted }\end{array}$ & $\begin{array}{l}\text { Corrected Item- } \\
\text {-total Correlation }\end{array}$ & $\begin{array}{l}\text { Squared Multiple } \\
\text { Correlation }\end{array}$ & $\begin{array}{l}\text { Cronbach's } \\
\text { Alpha if } \\
\text { Item Deleted }\end{array}$ \\
\hline 1 & 185.0063 & 319.843 & .328 & .330 & .810 \\
\hline 2 & 185.2452 & 322.844 & .180 & .280 & .813 \\
\hline 3 & 185.6540 & 319.653 & .204 & .262 & .813 \\
\hline 4 & 184.9175 & 319.853 & .327 & .350 & .810 \\
\hline 5 & 185.7405 & 320.049 & .166 & .227 & .815 \\
\hline 6 & 185.3373 & 320.843 & .237 & .206 & .812 \\
\hline 7 & 184.9270 & 317.354 & .387 & .411 & .809 \\
\hline 8 & 185.3444 & 317.119 & .358 & .363 & .809 \\
\hline 9 & 186.5238 & 331.471 & -.056 & .306 & .821 \\
\hline 10 & 185.1548 & 319.113 & .293 & .311 & .811 \\
\hline 11 & 185.0532 & 317.348 & .393 & .343 & .809 \\
\hline 12 & 185.7444 & 317.287 & .350 & .289 & .809 \\
\hline 13 & 184.9810 & 316.900 & .424 & .401 & .808 \\
\hline 14 & 185.1333 & 312.926 & .472 & .443 & .807 \\
\hline 15 & 185.5286 & 324.505 & .116 & .260 & .815 \\
\hline 16 & 185.7135 & 317.749 & .290 & .308 & .811 \\
\hline 17 & 185.3810 & 317.323 & .358 & .321 & .809 \\
\hline 18 & 185.7159 & 325.589 & .087 & .283 & .816 \\
\hline 19 & 185.5238 & 318.408 & .261 & .315 & .811 \\
\hline 20 & 185.0873 & 316.494 & .431 & .420 & .808 \\
\hline 21 & 184.9992 & 317.674 & .389 & .446 & .809 \\
\hline 22 & 185.0056 & 316.805 & .397 & .400 & .809 \\
\hline 23 & 186.3040 & 328.749 & -.002 & .226 & .820 \\
\hline 24 & 185.3802 & 319.812 & .237 & .388 & .812 \\
\hline 25 & 184.9032 & 317.311 & .381 & .407 & .809 \\
\hline
\end{tabular}




\begin{tabular}{|c|c|c|c|c|c|}
\hline 26 & 185.4310 & 313.623 & .378 & .345 & .808 \\
\hline 27 & 185.9746 & 319.221 & .201 & .373 & .813 \\
\hline 28 & 185.6183 & 311.917 & .476 & .477 & .806 \\
\hline 29 & 185.7762 & 314.976 & .386 & .477 & .808 \\
\hline 30 & 185.7841 & 313.459 & .413 & .506 & .808 \\
\hline 31 & 185.8183 & 314.204 & .377 & .513 & .808 \\
\hline 32 & 185.2167 & 314.459 & .468 & .495 & .807 \\
\hline 33 & 185.1556 & 316.284 & .414 & .516 & .808 \\
\hline 34 & 185.0976 & 314.274 & .460 & .519 & .807 \\
\hline 35 & 184.8738 & 317.233 & .421 & .420 & .809 \\
\hline 36 & 185.8119 & 318.761 & .217 & .309 & .813 \\
\hline 37 & 185.2071 & 316.403 & .422 & .374 & .808 \\
\hline 38 & 185.2659 & 313.833 & .483 & .478 & .807 \\
\hline 39 & 185.0040 & 317.048 & .407 & .467 & .809 \\
\hline 40 & 185.1889 & 315.545 & .453 & .452 & .808 \\
\hline 41 & 186.3889 & 328.724 & .001 & .153 & .819 \\
\hline 42 & 186.6175 & 317.177 & .227 & .693 & .813 \\
\hline 43 & 186.6468 & 314.494 & .257 & .800 & .812 \\
\hline 44 & 186.6651 & 314.078 & .241 & .776 & .813 \\
\hline 45 & 186.5040 & 318.257 & .227 & .765 & .812 \\
\hline 46 & 186.4381 & 318.049 & .245 & .772 & .812 \\
\hline 47 & 186.4984 & 321.014 & .184 & .553 & .814 \\
\hline 48 & 186.9476 & 329.746 & -.020 & .218 & .820 \\
\hline 49 & 186.8730 & 326.985 & .030 & .310 & .819 \\
\hline 50 & 186.6040 & 331.979 & -.067 & .227 & .822 \\
\hline 51 & 186.6563 & 324.750 & .071 & .375 & .818 \\
\hline 52 & 186.7817 & 323.254 & .119 & .364 & .816 \\
\hline
\end{tabular}

From Table 3, any item with a 'Corrected item-Total Correlation' of less than 0.2 was marked as an item to be deleted. These set of items are those showing an increase in scale's Cronbach's Alpha and mean when they were deleted. Thus, from Table 2, items 2, 5, 9, 15, $18,23,41,47,48,49,50,51$ and 52 are those with the characteristics of improving the scale's reliability when deleted from the scale. They were therefore supposed to be deleted. However, it is worthy of mention that no item was eliminated from the whole scale based on the information obtained from item-total statistics (in Table 2). The decision to delete any of the items was suspended until the stage when the reliability of each of the sub-scales (factors) was ascertained.

Research Question 2: What is the internal consistency reliability of the scale? 
Investigation into the reliability of the TES was conducted using the reliability tool under scale in the SPSS programme. Data was subjected to internal consistency reliability analyses; the first, Combach's Alpha and the second, split-half reliability. For the split-half reliability, both Spearman Brown Split-Half and Guttman Split-Half coefficients were obtained for the scale in general and for each of the factors (subscales). The results of reliability test presented in Table 4 were obtained from the analysis conducted on the 52 -item version administered on the sample before the delete of poor items.

Table 4. Coefficients of Reliability Tests

$\begin{array}{lcc}\text { No of Items } & 52 & \mathrm{p} \\ \text { Cronbach's Alpha } & 0.82 & <0.05 \\ \text { Spearman-Brown Coefficient (Equal Length) } & 0.87 & <0.05 \\ \text { Guttman Split-Half Coefficient } & 0.86 & <0.05\end{array}$

A Cronbach's Alpha of 0.82 was obtained. However, in order to preclude the possibility of taking wrong inference on the reliability of the scale, the data was also subjected to split-half analyses. Here, two results were obtained. They are the Spearman Brown Splithalf coefficients and the Guttman Split-half coefficients.

The value of the Spearman Brown Split-half coefficient for the scale is 0.87 (equal length). Also, that of Guttman Split-half is 0.86. The two coefficients are high and good enough to declare that the scale is reliable. All the coefficients were significant and good enough to conclude that the TES is reliable. DeVellis (1991) posited that “..... an alpha below 0.60 is unacceptable; $0.60-0.65$ undesirable; $0.65-0.70$ minimally acceptable; $\quad 0.70-$ 0.80 respectively, $0.80-0.90$ very good and if much above 0.90 excellent ...” (p.4). Although the 52-item version of the TES is reliable, its reliability coefficient could be increased by looking more closely to the contribution of each of the items to the particular factor it was meant to measure. This led to the sub-scale reliability analysis, the result of which was used in item removal from or retention on the TES. 
Sub-Scale Reliability Coefficients of the TES was considered using the six factors listed in Table 1. The result of the sub-scale reliability investigations for the six factors showed that each of the six factors on the 52-item version has varying reliability coefficients. Each of the factor properties showed improvement after the removal of items that had low corrected item-total correlation coefficients. The trend is as presented in Table 5.

The corrected item-total correlation of each of the sub-scales was considered as well as their reliability coefficients. These were used in taking decisions that led to the removal of 17 items on the scale, leading to the retention of 35 items on the second version of the TES.

Table 5. Subscale Reliability Coefficients Before and after the Removal of Weak Items

\begin{tabular}{clcccc}
\hline Factor & & No of Items & Mean & S.D. & 'r' Coefficient \\
\hline 1 & Before Item Reduction & 15 & 61.10 & 6.98 & 0.63 \\
& After Item Reduction & 14 & 55.47 & 6.88 & 0.70 \\
2 & Before Item Reduction & 11 & 41.85 & 5.90 & 0.53 \\
& After Item Reduction & 7 & 24.93 & 4.92 & 0.68 \\
3 & Before Item Reduction & 10 & 30.31 & 4.44 & 0.56 \\
& After Item Reduction & 6 & 22.81 & 4.05 & 0.65 \\
4 & Before Item Reduction & 6 & 23.16 & 3.47 & 0.57 \\
& After Item Reduction & 5 & 20.22 & 3.31 & 0.72 \\
5 & Before Item Reduction & 4 & 15.61 & 2.22 & 0.27 \\
& After Item Reduction & 2 & 8.53 & 2.60 & 0.60 \\
6 & Before Item Reduction & 6 & 21.02 & 3.84 & 0.51 \\
& After Item Reduction & - & - & - & - \\
\hline
\end{tabular}

The Second Stage of Development of TES for Nigerian Secondary School Teachers

The sub-scale reliability analysis led to the removal of 17 items. The remaining 35item version (hereafter referred to as the $2^{\text {nd }}$ Version of TES) has a Cronbach's Alpha of 0.85 and a split half coefficient of 0.71. Thus, the Cronbach's Alpha and the Spearman Brown split-half coefficients of the $2^{\text {nd }}$ version of the TES were high enough to adjudge the scale as reliable. However, a further look at the item total statistics of the 35-item version showed that it could still be improved. Details about the summary item statistics for the 2nd Version of the TES could be found in Table 6 .

Table 6. Summary Item Statistics for the $2^{\text {nd }}$ Version of the TES. 


\begin{tabular}{lllllll}
\hline & Mean & $\begin{array}{l}\text { Mini- } \\
\text { mum }\end{array}$ & $\begin{array}{l}\text { Maxi- } \\
\text { mum }\end{array}$ & Range & Variance & $\begin{array}{l}\text { Number } \\
\text { of Ítems }\end{array}$ \\
Item Means & 3.84 & 2.63 & 4.43 & 1.80 & 0.27 & 35 \\
$\begin{array}{l}\text { Item variance } \\
\text { Inter-Item }\end{array}$ & 17 & 0.72 & 2.59 & 1.89 & 0.22 & 35 \\
$\begin{array}{l}\text { Correlation } \\
\text { o.t }\end{array}$ & & -0.16 & 0.82 & 0.98 & 0.02 & 35 \\
\hline
\end{tabular}

The item means of the $2^{\text {nd }}$ version of the TES is 3.84. This is high enough considering the fact that the highest weight attached to each of the responses of the item is 5 . The variance of 1.12 is low and what this means is that respondents differed minimally on the average to the items on the scale. The Cronbach's Alpha coefficient of 0.85 obtained for the scale is rated 'very good' by Devellis (1991) and thus, it could be adjudged good enough for use on Nigeria teachers. The $2^{\text {nd }}$ version of the TES contains items that are very close in strength. They are items with "Cronbach's Alpha if item Deleted" that are almost the same for the 35 items. See Table 7 (for detail).

Table 7. Item Total Statistics for $2^{\text {nd }}$ Version

\begin{tabular}{|c|c|c|c|c|c|}
\hline $\begin{array}{l}\text { Item } \\
\text { No. }\end{array}$ & $\begin{array}{l}\text { Scale Mean if } \\
\text { Item Deleted }\end{array}$ & $\begin{array}{l}\text { Scale Variance } \\
\text { if Item Deleted }\end{array}$ & $\begin{array}{l}\text { Corrected } \\
\text { Item-Total } \\
\text { Correlation }\end{array}$ & $\begin{array}{l}\text { Squared } \\
\text { Multiple } \\
\text { Correlation }\end{array}$ & $\begin{array}{l}\text { Cronbach's } \\
\text { Alpha if Item } \\
\text { Deleted }\end{array}$ \\
\hline 2 & 130.2864 & 224.732 & .231 & .208 & .848 \\
\hline 3 & 130.7313 & 222.746 & .222 & .198 & .849 \\
\hline 4 & 129.9562 & 223.327 & .343 & .256 & .845 \\
\hline 5 & 130.8041 & 220.891 & .236 & .159 & .849 \\
\hline 7 & 129.9689 & 221.794 & .384 & .326 & .844 \\
\hline 8 & 130.4088 & 220.941 & .366 & .256 & .845 \\
\hline 11 & 130.0757 & 221.906 & .386 & .263 & .844 \\
\hline 12 & 130.7878 & 221.150 & .359 & .221 & .845 \\
\hline 13 & 130.0269 & 220.715 & .441 & .351 & .843 \\
\hline 14 & 130.2065 & 217.959 & .468 & .368 & .842 \\
\hline 16 & 130.8069 & 221.826 & .280 & .231 & .847 \\
\hline 17 & 130.4696 & 220.449 & .384 & .267 & .844 \\
\hline 19 & 130.5785 & 221.859 & .274 & .262 & .847 \\
\hline 20 & 130.1386 & 220.369 & .454 & .364 & .843 \\
\hline 21 & 130.0672 & 220.722 & .420 & .380 & .844 \\
\hline 22 & 130.0545 & 220.925 & .401 & .364 & .844 \\
\hline 24 & 130.4052 & 223.682 & .239 & .315 & .848 \\
\hline 25 & 129.9533 & 221.150 & .402 & .376 & .844 \\
\hline 26 & 130.4774 & 217.358 & .412 & .308 & .843 \\
\hline 27 & 131.0028 & 222.035 & .232 & .246 & .849 \\
\hline 28 & 130.6697 & 216.001 & .505 & .414 & .841 \\
\hline 29 & 130.8289 & 218.841 & .410 & .424 & .843 \\
\hline
\end{tabular}




\begin{tabular}{llllll}
30 & 130.8586 & 217.136 & .457 & .472 & .842 \\
31 & 130.8635 & 217.652 & .417 & .462 & .843 \\
32 & 130.2751 & 218.692 & .487 & .428 & .842 \\
33 & 130.1994 & 219.642 & .461 & .430 & .843 \\
34 & 130.1464 & 218.257 & .495 & .453 & .842 \\
35 & 129.9342 & 220.674 & .456 & .377 & .843 \\
38 & 130.3260 & 218.220 & .506 & .431 & .842 \\
39 & 130.0743 & 220.082 & .448 & .440 & .843 \\
40 & 130.2489 & 219.308 & .477 & .436 & .842 \\
42 & 131.6704 & 224.368 & .157 & .666 & .852 \\
43 & 131.7277 & 222.094 & .189 & .774 & .851 \\
44 & 131.7313 & 221.854 & .175 & .742 & .853 \\
46 & 131.4781 & 225.161 & .163 & .495 & .851 \\
\hline
\end{tabular}

The value of "Cronbach's Alpha if Item Deleted" for 21 out of the 35 items is 0.85 while the "Cronbach's Alpha if item Deleted" for the remaining 14 items is 0.84. Again, the "Scale Mean if item Deleted" is approximately 131 for most items with the exception of four items that are approximately 132. This suggests a possibility of further removing some of the items on the scale to obtain a stronger TES. This led to a third order reliability analyses.

\section{The Third (Final) Version of TES for Nigerian Secondary School Teachers}

A reliability analysis conducted to examine the internal consistency of the 24 items left showed that the TES a Cronbach's Alpha and Split-half coefficients of 0.88 and 0.90 respectively. These coefficients were very good to warrant the declaration of the 24-item TES as reliable (DeVellis, 1991). It is better than 0.82 obtained for the first 52-item version and 0.85 alpha coefficient for the second version (containing 35 items). In order to be sure that none of the 24 items needed to be deleted so as to increase the scale's Cronbach's Alpha, the scale item-total statistics was examined. This is presented in Table 8 .

Table 8. Item-Total Statistics of the Final Version of the TES.

\begin{tabular}{|c|c|c|c|c|c|}
\hline $\begin{array}{l}\text { Item } \\
\text { No. }\end{array}$ & $\begin{array}{l}\text { Scale Mean if } \\
\text { Item Deleted }\end{array}$ & $\begin{array}{l}\text { Scale Variance } \\
\text { if Item Deleted }\end{array}$ & $\begin{array}{l}\text { Corrected } \\
\text { Item-Total } \\
\text { Correlation }\end{array}$ & $\begin{array}{l}\text { Squared } \\
\text { Multiple } \\
\text { Correlation }\end{array}$ & $\begin{array}{l}\text { Cronbach's } \\
\text { Alpha if Item } \\
\text { Deleted }\end{array}$ \\
\hline 4 & 92.8559 & 138.209 & .401 & .249 & .879 \\
\hline 7 & 92.8699 & 137.294 & . 427 & 293 & .878 \\
\hline 8 & 93.3138 & 136.893 & .392 & .241 & .879 \\
\hline 11 & 92.9713 & 137.778 & .408 & .247 & .879 \\
\hline 12 & 93.6888 & 138.140 & .337 & .174 & .881 \\
\hline 13 & 92.9554 & 135.983 & .497 & .316 & .877 \\
\hline 14 & 93.1173 & 134.578 & .491 & .309 & .877 \\
\hline
\end{tabular}




\begin{tabular}{llllll}
17 & 93.4158 & 136.618 & .386 & .220 & .880 \\
20 & 93.0344 & 136.871 & .462 & .320 & .878 \\
21 & 92.9981 & 137.009 & .413 & .338 & .879 \\
22 & 92.9739 & 136.218 & .443 & .363 & .878 \\
25 & 92.8622 & 136.946 & .422 & .331 & .879 \\
26 & 93.3807 & 133.753 & .441 & .311 & .878 \\
28 & 93.5619 & 133.796 & .499 & .348 & .876 \\
29 & 93.7411 & 136.225 & .384 & .384 & .880 \\
30 & 93.7691 & 133.873 & .479 & .452 & .877 \\
31 & 93.7634 & 134.388 & .434 & .436 & .879 \\
32 & 93.1958 & 134.309 & .536 & .401 & .875 \\
33 & 93.0931 & 136.137 & .470 & .332 & .877 \\
34 & 93.0580 & 133.413 & .567 & .422 & .875 \\
35 & 92.8476 & 135.712 & .525 & .358 & .876 \\
38 & 93.2430 & 133.592 & .581 & .418 & .874 \\
39 & 92.9879 & 134.985 & .533 & .403 & .876 \\
40 & 93.1543 & 135.349 & .512 & .383 & .876 \\
\hline
\end{tabular}

The item-total statistics for the 24-items Final Version of the TES are very similar. The 'scale mean if item Deleted' for each of the items is either 92 or 93. The 'Corrected ItemTotal Correlation' for each of the items ranges between 0.34 and 0.58. The Cronbach's Alpha if item Deleted' for all the 24 items is 0.88 except for item 38 which is 0.87 . What this means is that the items have almost equal psychometric value in the scale.

Research Question 3: What is the Factorial Validity of the TES?

The data generated from the administration of the 52-item TES was subjected to factor analysis. The initial unrotated factor solution using principal component analysis suggested 15 factors (with eigenvalues great than one), which accounted for $61.21 \%$ of the total scale variance. However, the scree plot produced three factors. The factors are:

i. Efficacy to influence student's learning

ii. $\quad$ Efficacy to instill discipline in students

iii. Efficacy to enlist parental involvement 


\section{Scree Plot}

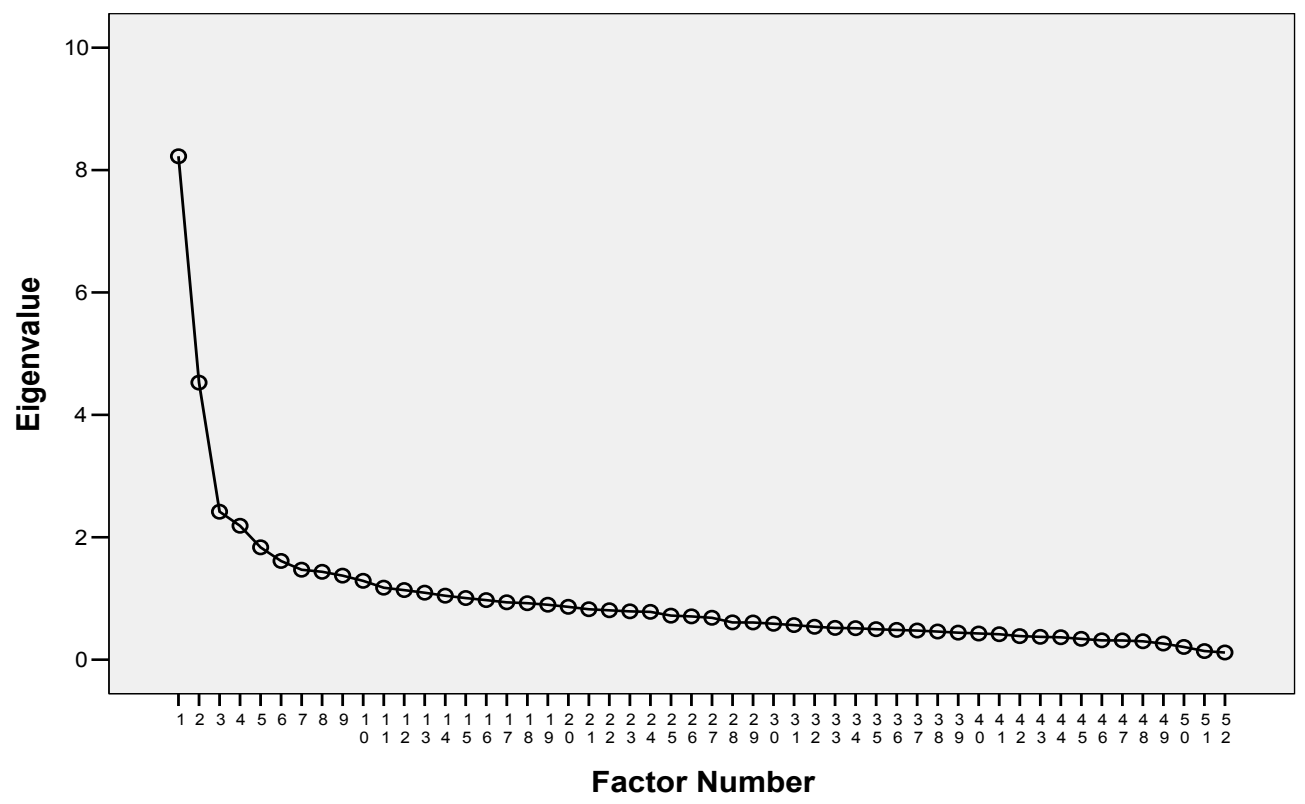

Figure 1. Screen Plot for the 52-Item Version of TES

After the reliability analyses, the number of items subjected to the second round factor analysis was 35 . A further reduction of the items of the scale led to the 24 -item final version. Although, Principal Component Analysis with varimax rotation that produced the final version suggested six factors; rotation converged in eight iterations. However, scree plot suggested only two factors. This is in Figure 2.

Scree Plot

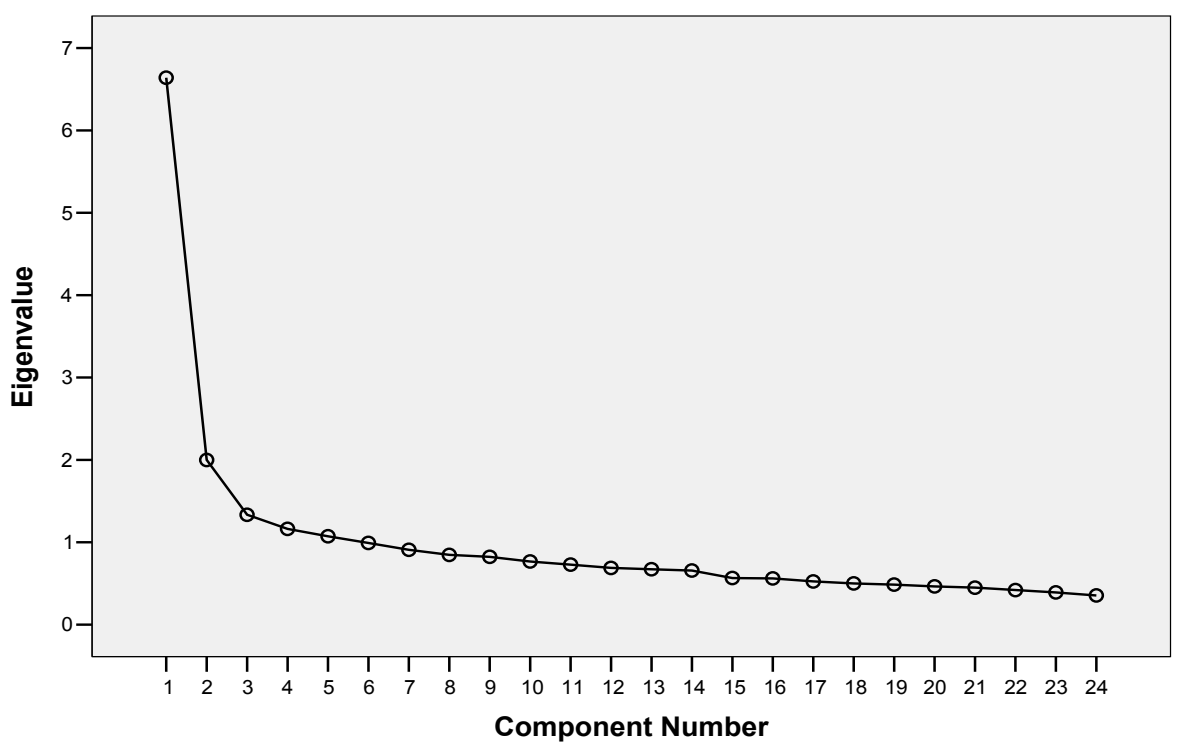

Figure 2. Screen Plot of the Final Version of the TES 
Factor analysis showed that the initial eigenvalue greater than 1 suggested that there were four factors on the TES (final version) which accounted for $46.40 \%$ of the total scale variance. However, scree plot showed that there were only two factors. The two factors are efficacy to influence students' learning and the second factor is efficacy to enlist parental involvement. They are regarded as internal (i.e. within the control of the teacher) and external (i.e. not within his control) respectively.

Research Question 4: On which Factors did the Items on the TES Load?

The coefficients listed in Table 9 represent the item loadings on each of the two factors of the TES.

The 24 items on the TES loaded on efficacy to influence students' learning, which is internal to the teacher $(4,7,8,11,12,13,14,20,21,22,17,32,33,34,35,38,39,40)$ and efficacy to enlist parental support (which is external to the teacher. $(25,26,28,29,30,31)$. The coefficients of items loading for Factors 1 (Efficacy to influence student's learning) were not as high as those for Factor 2.

Table 9. Item Loadings on each of the 2 Factors on the TES

\begin{tabular}{|c|c|c|}
\hline $\begin{array}{l}\text { Item } \\
\text { No }\end{array}$ & Factor 1 & Factor 2 \\
\hline 4 & 0.39 & - \\
\hline 7 & 0.62 & - \\
\hline 8 & 0.52 & - \\
\hline 11 & 0.36 & - \\
\hline 12 & 0.38 & - \\
\hline 13 & 0.39 & - \\
\hline 14 & 0.46 & - \\
\hline 17 & 0.44 & - \\
\hline 20 & 0.52 & - \\
\hline 21 & 0.66 & - \\
\hline $\begin{array}{l}\text { Item } \\
\text { No }\end{array}$ & Factor 1 & Factor 2 \\
\hline 22 & 0.57 & - \\
\hline 25 & - & 0.61 \\
\hline 26 & - & 0.42 \\
\hline 28 & - & 0.59 \\
\hline 29 & - & 0.74 \\
\hline 30 & - & 0.61 \\
\hline 31 & - & 0.70 \\
\hline
\end{tabular}




\begin{tabular}{lll}
32 & 0.67 & - \\
33 & 0.64 & - \\
34 & 0.55 & - \\
35 & 0.58 & - \\
38 & 0.67 & - \\
39 & 0.67 & - \\
40 & 0.61 & - \\
\hline
\end{tabular}

\section{Discussion}

The instrument administered contained 52 items having seven hypothesized dimensions. Only three out of the seven dimensions listed on the 52-item version (administered) at the initial stage of analyses satisfied the factorial validity test (done through the use of EFA) and reliability analysis (through the use of 'corrected item-total correlation' and 'Cronbach's alpha coefficient if item deleted'. A total of 28 items were dropped from the scale. Parts of the reasons for dropping them included negative or very low corrected itemtotal correlation (e.g. items 2, 5, 9 and 15), low item loadings (e.g. items 1, 3, 6, 9, 10, 18, 23, 24, 27, 36, 41, 49 and 50). The other reason was the issue of Cronbach's alpha coefficient if item deleted'. Items deleted using this decision rule included items 19, 37, 42, 43, 44, 45, 46, 47, 48, 51 and 52. Thus, the item loadings, inter-item correlations and the Cronbach's alpha for the final version (24 items) were consistent with the conditions specified in literature (e.g. DeVellis, 1991; Tschannen-Moran and Woolfolk-Hoy, 2001; Scaledevstat website undated(accessed on $14^{\text {th }}$ February, 2005) The items so removed were dropped in order to increase the homogeneity of the items on the scale, increase reliability, and also increase confidence in the stability of measure. The inability of some of the items meant for the sampling of dimensions as reaching the poor, support of colleges and universities around, and overcoming work challenges could not scale through the requirement for inclusion in the final scale. The implication of this was that the items needed to be revisited for moderation or rewording so as to improve their capacity at capturing the factors for which they are intended.

In theory, a number of factors affect the reliability of any measuring instrument especially attitude scale like the TES. The factors include group homogeneity and the length of the instrument (Kerlinger, 1986; Popham, 2002). The differences in the efficacy of the sample used could have been taken care of by the large sample involved in the study as well as the long length of the TES. This was agreement with the recommendation of Sarantakos 
(2003) that large samples be involved in survey so as to reduce sampling error and obtain a more reliable result. When a small sample is employed in a study, the differences between the characteristics of the sample and that of the population could affect the reliability (positively or otherwise) of the result as well as the generalization made.

In scaling, factor analysis - a data reduction technique - is used to determine the item loadings on the various dimensions of the scale via the EFA method. However, in the use of EFA (such as the one employed in this study), the investigator was the one to decide how many factors to extract from the emerging scale (Roberts \& Henson, 2001). This decisiontaking challenge has, in a way, led to the emergence of varying number of factors from one study to the other. For example, two-factor solution emerged from the study of researchers like Rotter (1966), Woolfolk and Hoy (1990), Tschannen-Moran, Woolfolk-Hoy \& Hoy (1998) and Roberts \& Henson (2001). Some other investigators of TE scales came up with three factor solutions. Those in this category included Emmer \& Hickman (1990), Soodak \& Podell (1996) and Denzine, Cooney \& McKenzie (2005). came up with four factors in Taiwan although; the fit of the four-factor solution to TES validation has not been tested in literature, unlike the one, two or three factor solutions/dimensions (Brouwers, 2003).

Two dimensions emerged from this scale: student learning and parental involvement. The first, i.e. efficacy to influence student learning, is internal to the teacher while the second dimension, efficacy to elicit parental involvement, is external to the teacher. This outcome was in line with the dimensions obtained by Gibson \& Dembo (1985) and Hoy \& Woolfolk (1993) when they subjected TES to EFA and CFA.

Students' learning is internal to the teacher and is equivalent to self efficacy expectation theorized by Bandura (1997). The second factor, 'parental involvement' is external to the teacher and falls under Bandura's outcome expectancy part of self efficacy. Its external nature was hinged on the argument that the teacher could do less to influence the response of parents to the educational needs of their wards. What the teacher could do is to appeal and solicit support of the home; responses to such appeals may or may not be impressive. This result fit adequately to the classification of not only Gibson \& Dembo (1984) but also Hoy \& Woolfolk (1993). They however argued that while the first factor is internal to the teacher, the second factor is the consequences of his/her action and are therefore beyond his/her control. Thus, it is an external factor. It is worthy of mention 
however, that the internal-external dimensions of TES as theorized by Bandura (1997) still suggested very strongly that $\mathrm{TE}$ is a product of two main dimension: self efficacy and outcome expectation.

\section{References}

Achimugu, L. (2001). The Agonies of Nigeria Teachers: NUT, Friend or Foe. In Book Review, Tamabori: Kano Journal of Education, 6(2), 278-282.

Allinder, R. M. (1994). The relationship between efficacy and the instructional practices of special education teachers and consultants. Teacher Education and Special Education, $17,86-95$.

Bandura, A. (1977). Self-efficacy: Towards a unifying theory of behavioural change. Psychological Review, 84, 191-215.

Bandura, A (1986). Social Foundations of thoughts and actions: A Social Cognitive theory. Englewood Cliffs, NJ: Prentice Hall.

Bandura, A. (1990, Unpublished). Teacher Self-Efficacy Scale. Available on-line at: http://www.coe.ohio-state.edu/ahoy/researchinstruments.htm\#Ban

Bandura, A. (1997). Self-efficacy: The exercise of control. New York: W. H. Freeman and Company.

Brouwers, A. (2003). A test of the factorial validity of the teacher efficacy scale. Research. Research in Education. Available at: http://www.findarticles.com/particles/mi+qa3765/is_200305/ai n91945 3/print (1997). (Retrieved on $12^{\text {th }}$ February, 1997)

Campbell, J. (1996). A Comparison of Teacher Efficacy for Pre and In-Service Teachers in Scotland and America. Education, Fall 1996. Available at: http://www.findarticles.com/p/articles/mi_qa3673/is199610/ai_n8742131/

Coladarci, T. \& Fink, D. R. (1995). Correlations among measures of teacher efficacy. Are they measuring the same thing? Paper presented at the annual meeting of the American Education Research Association. San Francisco.

Cronbach, L. J. (1951). Coefficient alpha and the internal structure of tests. Psychometrika, $16,297-334$.

Denzine, G. M.; Cooney, J. B. and McKenzie, R. (2005). Confirmatory Factor Analysis of the Teacher Efficacy Scale for Prospective Teachers. British Journal of Educational Psychology, 75, 689-708. 
DeVellis, R. (1991). Scale development: Theory and Applications. Newbury Park, CA: Sage.

Emmer, E. \& Hickman, J. (1990). Teacher decision making as a function of efficacy, attribution and reasoned action. Paper presented at the annual meeting of the American Educational Research Association, Boston, MA.

Gibson, S. \& Dembo, M. (1984). Teacher efficacy: A construct validation. Journal of Educational Psychology, 74(4), 569-582.

Guskey, T. \& Passaro, P. (1994). Teacher efficacy: A study of construct dimensions. American Educational Research Journal, 31, 627-643.

Hall, B.; Burley, W.; Villeme, M. \& Brockmerer, L. (1992). An attempt of explicate teacher efficacy beliefs among first year teachers. Paper presented at the annual meeting of the American Educational Research Association, San Francisco.

Henson, R.K. (2001). Teacher Efficacy Scale: Substantive Implications and Measurement Dilemmas. Keynote Address, Annual Meeting of the Educational Research exchange, Texas A \& M University, College Station, Texas. Available at: http://www.css.edu/users/dswenson/web/scaledevstat.html $\quad$ (Retrieved on $14^{\text {th }}$ February, 2005)

Hoy, W. K. and Woolfolk, A. E. (1993). Teachers' Sense of Efficacy and the Organisational Health of Schools. The Elementary School Journal, 93, 356-372.

Kerlinger, F. N. (1986). Foundations of behavioural research. New York: Holt, Rinehart \&Winston.

Likert, R. (1932). A Technique for the Measurement of Attitudes. New York: Columbia University Press.

Magogwe, J. M. (2006). The Relationship between Proficiency and Self Efficacy Beliefs of the University of Botswana Students Learning ESL. Marang, Vol. 16, 121 - 131.

Okebukola, P. (2002). Teacher Education in Nigeria: Past, Present and Future. In A. M. Mohammed and A. Umar, Teacher Education in Nigeria: Past, Present and Future. Kaduna: National Teachers' Institute.

Pajares, F. (1996). Self-efficacy beliefs in academic settings. Review of Educational Research, 66, 533-578.

Popham, W. J. (2002). Classroom Assessment, What teachers need to know. Boston: Allyn \& Bacon.

Roberts, J. K. and Henson, R. K. (2001). A Confirmatory Factor Analysis of a New Measure of Teacher Efficacy: Ohio State Teacher Efficacy. Paper Presented at the Annual 
Meeting of the American Educational Research Association, Seattle, April 10-14, 2001.

Rotter, J. B. (1966). Generalized expectancies for internal versus external control of reinforcement. Psychological monographs, 80, 1-28.

Sarantakos, S. (2003 ed.). Social Research. South Yarra, (Australia): Macmillan Publishers.

Soodak, L. \& Podell, D. (1996). Teaching efficacy: Towards the understanding of a multifaceted construct. Teaching and Teacher Education, 12, 401-412.

Statistical Procedures for Scale Development. Available at:

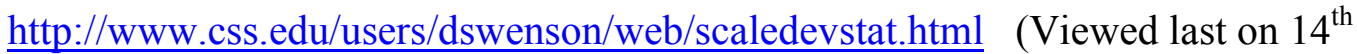

February, 2005)

Tschannen-Moran, M. \& Woolfolk-Hoy, A. (2001). Teacher efficacy. Capturing an elusive concept. Teaching and Teacher Education, 17, 783 -805.

Tschannen-Moram, M.; Woolfolk-Hoy, A. \& Hoy. W. K. (1998). Teacher efficacy: Its meaning and measure. Review of Educational Research, 68, 202 -248.

Woolfolk, A. E. \& Hoy, W. K. (1990)). Prospective Teachers' sense of efficacy beliefs about control. Journal of Educational Psychology, 82, 81-91. 